\title{
EVALUATION OF THE POTENTIAL FOR RARE EARTH ELEMENT (REE) DEPOSITS RELATED TO THE BORBOREMA PEGMATITE PROVINCE IN NORTHEASTERN BRAZIL.
}

\author{
Hartmut Beurlen ${ }^{1}$ \\ Dieter Rhede ${ }^{2}$ \\ Rainer Thomas ${ }^{2}$ \\ Marcelo Reis R. da Silva ${ }^{1}$ \\ Dwight R. Soares ${ }^{3}$ \\ 10.18190/1980-8208/estudosgeologicos.v29n2p40-53 \\ ${ }^{1}$ Department of Geology, Federal University of Pernambuco-UFPE-CTG; Graduate \\ Program (PPGC) Rua Acad. Hélio Ramos sn 50740-530, Recife Brasil; e-mail: \\ beurlen@terra.com.br or beurlen@ufpe.br \\ ${ }^{2}$ GeoForschungsZentrum Potsdam (GFZ)- Helmholtz Foundation, Telegrafenberg D- \\ 14473 Potsdam, Germany \\ ${ }^{3}$ Inst. Federal de Educação, Ciência e Tecnologia da Paraíba (IFPB), Nucleo de Estudos \\ de Pegmatitos (N-PEG) R. Tranquilino Coelho Lemos 671, 58100-000 Campina \\ Grande, Paraíba, Brazil
}

\begin{abstract}
Electron probe microanalyses (EPMA) of rare earth elements (REE) in xenotime, monazite, zircon, thorite and uraninite from different facies of pegmatitic granites supposed to be parental to complex rare element (REL) pegmatites of the Borborema Province (BPP) in Northeastern Brazil indicated monazite and xenotime as most common heavy accessory phases with significant enrichment in these elements. Averages of $\mathrm{Nd}$ and $\mathrm{Eu}$ in monazite are respectively 13.06 and $0.54 \mathrm{wt} . \%$ oxide and mean contents of Dy, Yb, Gd, and Er (respectively 4.77, 3.39, 3.15 and 3.86 wt. \% oxide) are found in xenotime. The other common accessory minerals like zircon, thorite, uraninite showed no significant enrichment in REE. Low xenotime and monazite contents in pegmatitic granites and their irregular distribution and reserves in pegmatites, turn the extraction directly from the hard rock impracticable. The REE-enriched minerals could however be enriched in and easily extracted from alluvial placers within the province. Ion adsorption REE enrichment could hypothetically form in parental granites of the pegmatites at the intersection with paleogeomorphologic plateaus culminated by the early Cenozoic siliciclastic Serra dos Martins Formation, because at this unconformity it is possible to observe an intensive kaolinization of the basement and lateritization of the covering sediments.
\end{abstract}

Keywords: Borborema Province, complex REL pegmatites, parental granites, possibility of related REE-deposits.

\section{RESUMO}

Análises de Elementos de Terras Raras (ETR) com microssonda eletrônica em xenotima, monazita, zircão, torita e uraninita de diferentes fácies de granitos pegmatíticos, supostos serem fonte de pegmatitos complexos de elementos raros (REL) na Província|Pegmatítica da Borborema (PPB) no Nordeste do Brasil, mostraram que a xenotima e monazita são os acessórios mais frequentes com significativa de (ETR). Conteúdos médios de $\mathrm{Nd}$ e Eu em monazita são respectivamente de 13,06 e 0,54 \% peso dos óxidos e de Dy, Yb, Gd, e 
Er respectivamente de 4,77, 3,39, 3,15 e 3,86 em xenotima, considerando apenas os óxidos de ETR mais caros no mercado. Os outros acessórios analisados, como zircão, torita, uraninita não apresentaram teores significativos de ETR. As reduzidas frequências modais da xenotima e monazita tanto nos granitos pegmatíticos como nos próprios pegmatitos tornam uma exploração das rochas duras impraticáveis. Os minerais com maior enriquecimento de ETR poderiam ser concentrados e explotados em placeres fluviais no âmbito da Província Pegmatítica. Há também a possibilidade de enriquecimento dos ETR a partir dos granitos parentais e pegmatitos na interseção dos plateaus paleo-geomorfológicos culminados pelos sedimentos siliciclasticos e caulinizados da Formação Serra dos Martins. Isto porque, na inconformidade na base da mesma ocorreu lateritização e intensa e profunda caulinização no embasamento cristalino subjacente, em condições similiares às das jazidas de "adsorção iônica" (hoje também conhecidas como "hospedadas em regolito caulinizado", como Zudong, maior jazida de terras raras pesadas) na China.

Palavras-chave: Província Borborema, pegmatitos complexos tipo REL, granitos parentais, possibilidade de depósitos de ETR relacionados.

\section{INTRODUCTION}

Electron probe microanalyses (EPMA) of rare earth elements (REE) in xenotime, monazite, zircon, thorite and uraninite from different facies of pegmatitic granites supposed to be parental to Rare Element (REL) pegmatites of the Borborema Pegmatite Province (BPP) in Northeastern Brazil were obtained originally for geochronological purposes. Preliminary results were published by Beurlen et al. (2009), using the chemical dating method developed by Suzuki \& Adachi (1991), Montel et al. (1994) and refined by Rhede et al. (1996). The results indicated similar ages of these granites and the spatially related gem- and Be-LiTa-bearing pegmatites, below $540 \mathrm{Ma}$ (Baumgartner et al. 2006, and Beurlen et al. 2009).

The exponential increase of the prices of some REE, up to several hundred thousand US dollars per ton of refined rare earth oxide (REO), as consequence of its application in components of a fast growing number of devices of the high-tech industry (e.g. Haxel et al 2002, Campos et al. 2015, Statistica 2019, Sreevidya 2017), justifies the use of the available data for an evaluation if there is a possibility of the existence of economic deposits related to the BPP granites and pegmatites.

\section{GEOLOGICAL BACKGROUND}

The Borborema Pegmatite Province (BPP) extends along the eastern and southeastern part of the Seridó Belt (SB) in the middle of the Northern Tectonic Sub-Province (NTSP) in the Borborema Tectonic Province (BTP) as defined by Brito Neves \& Fuck (2013). The BPP and NTSP are limited in the south by the Patos Lineament, a transcontinental shearzone correlated with the Garoua Lineament in Cameroun-Nigeria. The SB is composed of a Brasiliano (630 Ma, van Schmus et al. 2003) supracrustal sequence known as Seridó Group, that overlays a Paleoproterozoic basement dominated by orthogneisses and migmatites (Caicó Group) with some small Archean nuclei.

This basement dominates eastand westward of the SB. The Seridó Group (SG) is composed of basal gneisses, marbles, calc-silicate and amphibolites of the Jucurutu Formation, overlain by quartzites and metaconglomerates of the Equador 
Formation and the topmost sillimanite cordierite - garnet bearing biotite schist of the Seridó Formation. Biotite schists, quartzites and metaconglomerates of the SG are the host rocks of respectively $80 \%$ and $10 \%$ of the more than 750 known mineralized granitic pegmatites (Da Silva et al. 1995) of the $\mathrm{BPP}$ (encompassing from simple Be- to complex spodumene and lepidolite subtypes of the REL class-LCT family according to Černý's classification (Černý \& Ercit 2005). The remaining

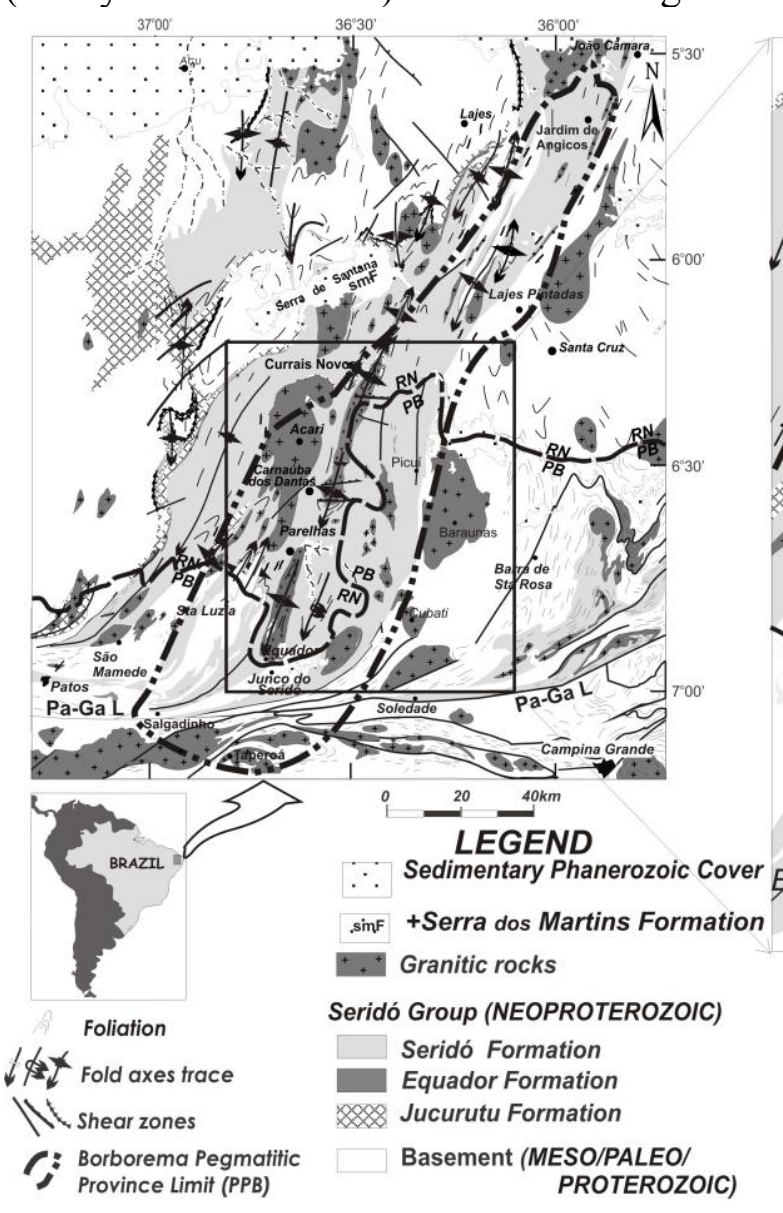

$10 \%$ of the pegmatites are intruded in Neoproterozoic granites, Jucurutu gneisses or basement rocks (Fig. 1).

The granite types found in the SB were grouped into four main phases, G1 to G4, by Jardim de Sá et al. (1981). As summarized in Beurlen et al. (2014), only syn- to late- tectonic G3 group granites and late to post-tectonic G4 granites may be considered as possible sources of the mineralized pegmatites.

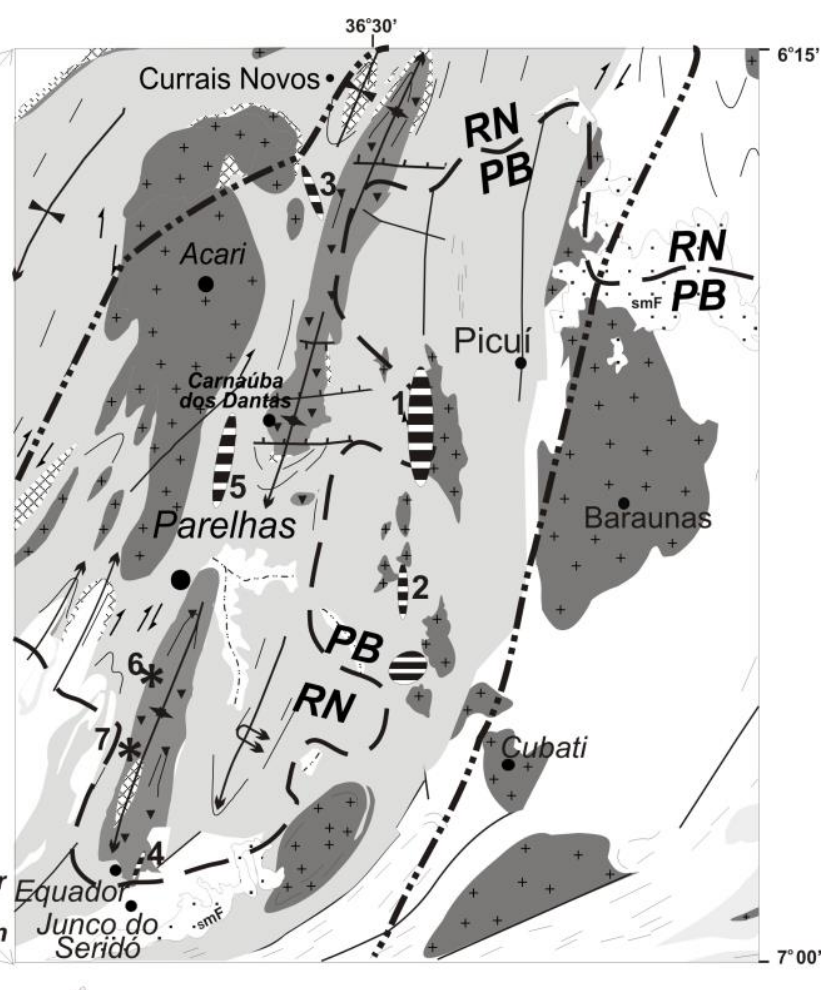

- Occurrences of pegmatitic granites and pegmatites referred to in the text:

1) Picuí; 2) Pedra Lavrada N; 3) Marcação;

4) Galo Branco; 5) Carnaúba dos Dantas W

* 6) Quintos and 7) Carrascão Pegmatites (Paraíba tourmaline bearing)

Figure 1 The Borborema Pegmatitic Province on a simplified geological base adapted from Brasil (1998, 2002), and the location of the studied pegmatitic granite intrusions and Quintos e Carrascão, "Paraíba Tourmaline" bearing pegmatites, modified from Beurlen et al. (2009).

G3 group granite types can probably also be excluded according to Jardim de Sá (1994) because ages of this group range around $580 \pm 30 \mathrm{Ma}$, typically related to the main stage of the Neoproterozoic Ediacaran(Brasiliano /Pan-African) Orogeny, much older than the wide range of the first pegmatite age 
determinations between 450 and $540 \mathrm{Ma}$, as discussed by Beurlen et al. (2008 and references therein).

The SG and its up to CambroOrdovician granites and pegmatitites in the BPP, are covered by an unfolded, supposedly early Cenozoic, 5 to $120 \mathrm{~m}$ thick sequence of sandstones and conglomerates called Serra do Martins Formation (SMF). According to Morais Neto and Alkmin (2001), the SMF occurred along a regional plateau at 500 to $850 \mathrm{~m}$ OSL, formed during a Cenozoic period of uplift and, due to subsequent erosion, remains preserved today only as "mesetas". At the unconformity (at around $750 \mathrm{~m}$ OSL in the area of the BPP), it is possible to observe a local lateritization in the covering sandstones and a very intensive kaolinization of the Neoproterozoic basement, including the pegmatites and granites.

\section{PETROGRAPHY OF PEGMATITIC GRANITES}

In the Picuí-Pedra Lavrada subarea of the BPP, da Silva (1993) distinguished several small "pegmatiticgranite" intrusions identified as group GR3 (including a medium grained hololeucocratic facies GR3A and a Kfeldspar megacryst bearing facies GR3B), as possible sources of Be-Li-Tabearing pegmatites. The occurence of intrusions with "pegmatitc-granite" facies is also mentioned in the G 4 group granites of Jardim de Sá (1994).
A boom of exploration of these pegmatitic-granites in the early 2000's for ornamental dimension-stones exposed large walls in several quarries (e.g. Figs. 2, 3 and 4) and allowed to distinguish a layered anatomy with four cyclically repeated facies in these granites, namely: 1) fine to medium grained leucogranite; 2) layered usually sodic and garnet bearing aplite from now on shortly "aplite", identical to the "line rock" as elsewhere described by Webber et al. (1997); 3) pegmatitic leucogranite with upward unidirectional growth of graphic K-felsdspar/quartz megaoikocrystals; 4) potassic pegmatite, with internal zoning and centripetal crystal growth, known as inward unidirectional solidification texture (UST). These facies are nearly identical to those described by Černý et al. (2005) in the Greer Lake leucogranite, considered to be the source granite of the Cat Lake pegmatite field with tantalum-rich lepidolite subtype pegmatites in Manitoba, Canada. A detailed description of the petrography, geochemistry, geological context and ages of these facies of five pegmatitic granites and related pegmatites of the BPP is available in Beurlen et al. (2009 and 2014). The petrographic investigation in these pegmatitic granites allowed verify that the highest modal content and homogeneous distribution of the potential REE bearing accessory minerals was the layered aplite facies. 


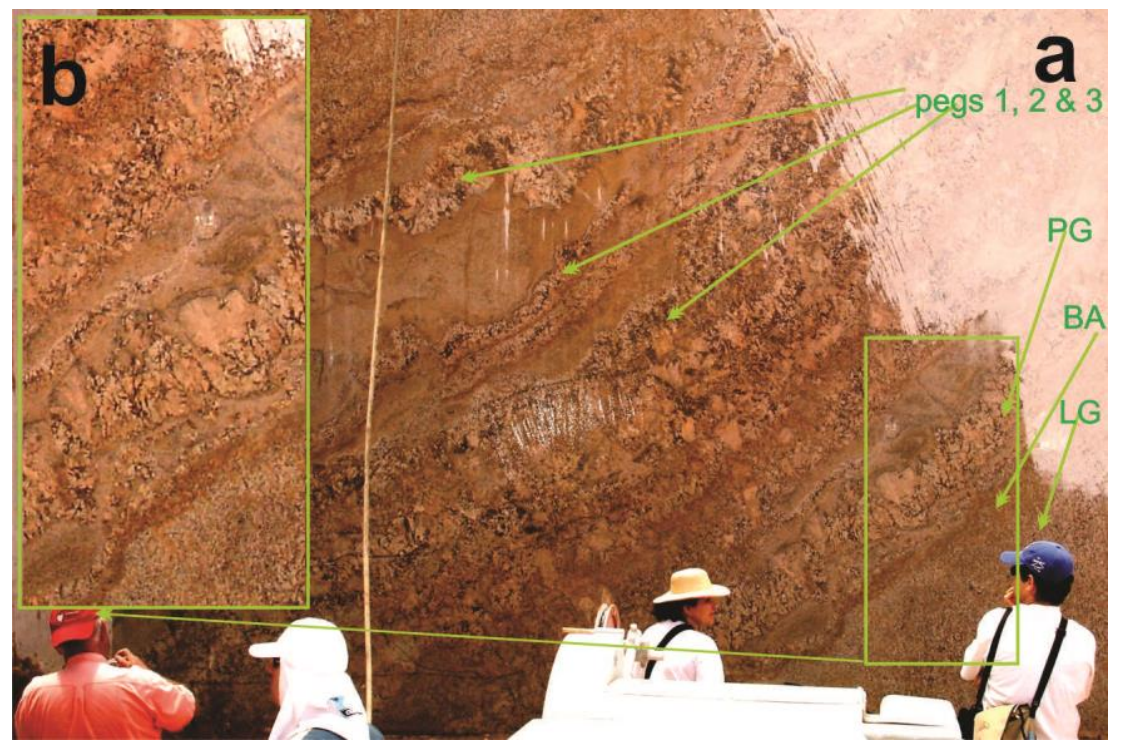

Figure 2 a) view of a $6 \mathrm{~m}$ high and $8 \mathrm{~m}$ wide bench of the Marcação pegmatitic granite quarry. It shows decimetric to metric layering formed by the rhythmic alternance of four facies: 1) equigranular fine (to medium) grained leucogranite (LG 1);2) millimeter sized rhythmic banded sodic aplite or "line rock" with garnet in the pink bands (BA 2);3) pegmatitic leucogranite (unidirectional upward growth of mega-oicocrysts of graphic feldspar+quartz (PG 3); 4) pegmatite veins with centripetal graphic feldspar crystal growth ("pegs 4"); b) detailed insert of a; (modified from Beurlen et al. 2014).

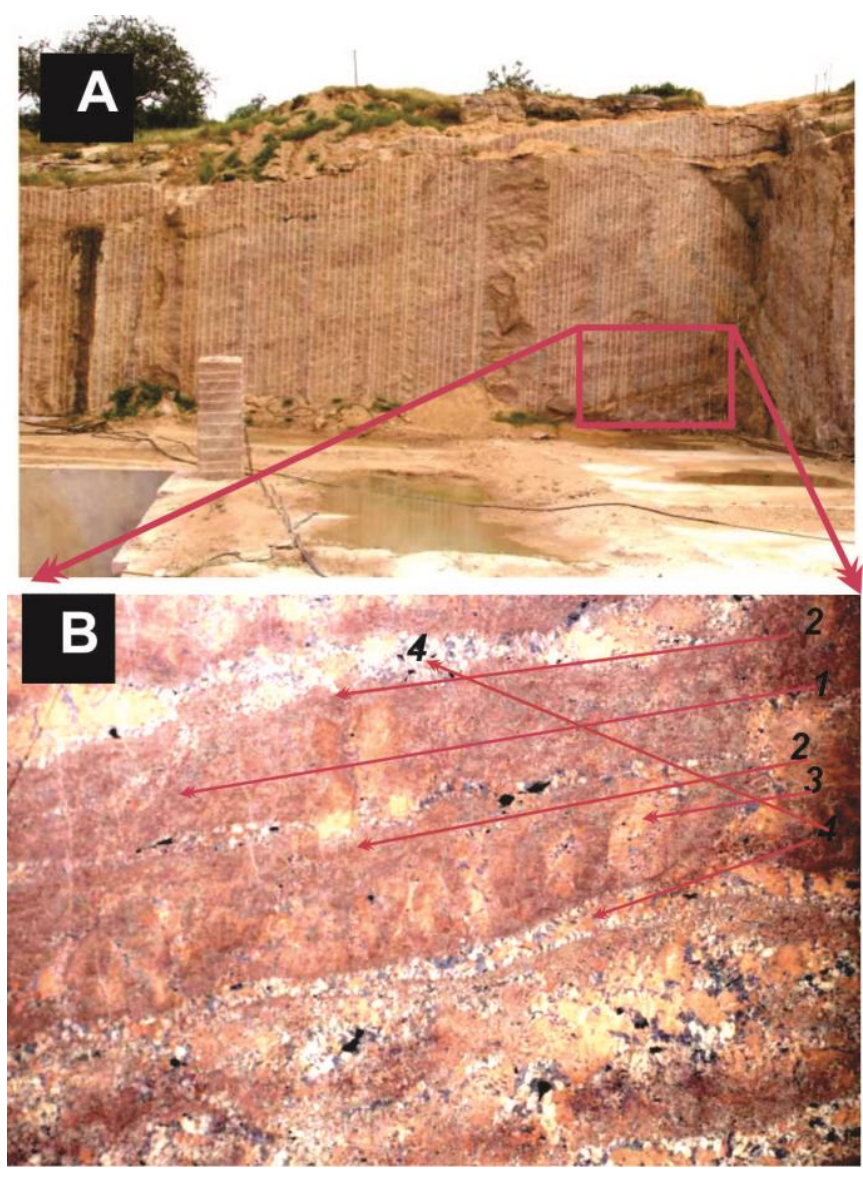

Figure 3A) View of a bench of the Picuí pegmatitic granite quarry with similar decimeter to meter sized layering of the four facies as described in Figure 2; B) detailed view of the different facies 1 to 4 ; modified from Beurlen et al. (2009). 

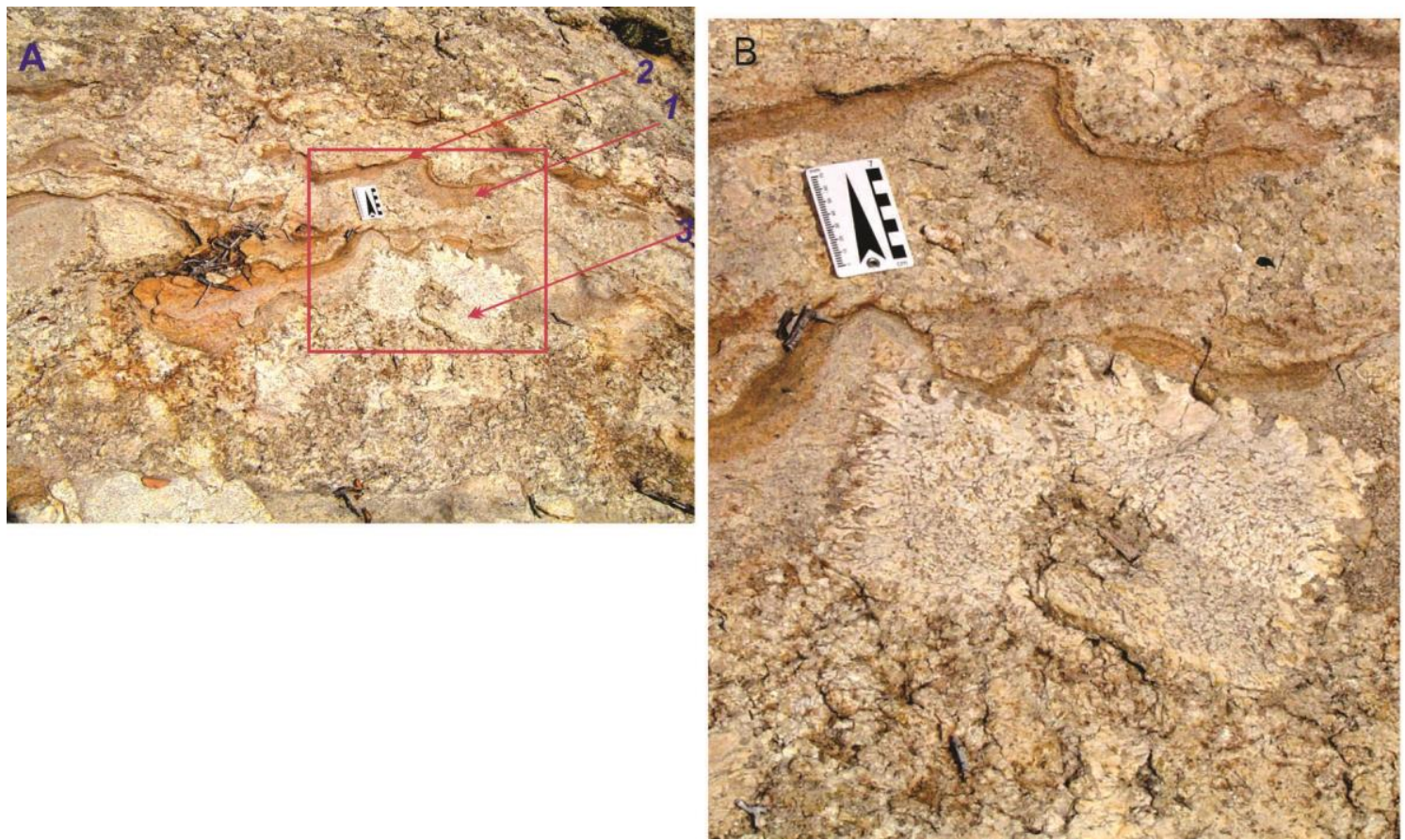

Figure 4 A) Outcrop of the Pedra Lavrada $N$ pegmatitic granite outcrop showing the layering of the "line rock" facies (2 - BA2), the equigranular facies (LG 1) and the megacryst facies (3). B) detail of A, showing a gradual coarsening of the grain size in the graphic quartz-feldspar megacryst.(PG 3). Modified from Beurlen et al. (2009). Modified from Beurlen et al. (2009).

\section{MINERAL CHEMISTRY}

\section{Methodological aspects}

Samples were collected of different facies from four pegmatiticgranite intrusions with quarries allowing a good systematic sampling of fresh samples and additionally one from a complex lepidolite-subtype pegmatite. After the petrographic characterization some representative polished thin sections were chosen for electron microprobe analyses of the accessory minerals with potential REEenrichment. Used standards were of synthetic refined REE phosphates.

Routine chemical analyses and backscattered electron images were performed with the JEOL JXA-8500F (hyperprobe) at the GeoForschungsZentrum Potsdam (GFZ)
- Helmholtz Centre Potsdam, - Potsdam Germany. Operating conditions for quantitative WDS analyses involved an accelerating voltage of $15 \mathrm{kV}$, a beam current of $40 \mathrm{nA}$, a beam diameter of 5 $\mu \mathrm{m}$, acquisition times of 100 to 300 seconds using five spectrometers LDE1 (F), TAB (Na, M g, Al, Si, Y), LIF (Mn, $\mathrm{Fe}, \mathrm{REEs}$ ), PET (P, Cl, Ti, Ca, Pb, Th, U) and LDEB (Be, B). The counting times on the peaks were $20 \mathrm{~s}$ for $\mathrm{Ca}, \mathrm{Fe}, \mathrm{Al}, \mathrm{P}$, and $\mathrm{Si}, 30 \mathrm{~s}$ for $\mathrm{Y}, 50 \mathrm{~s}$ for the REEs, 100 $\mathrm{s}$ for $\mathrm{Pb}$, Th, and $\mathrm{U}$. Matrix corrections were performed according to the Armstrong-CITZAF method (Armstrong 1995).

\section{Results}

The REE analyses of accessory minerals from the different facies of these supposed parental pegmatitic 
granites and pegmatites of the BPP (localization in Fig 1) allowed to recognize monazite and xenotime as main phases (with highest modal content) and with significant enrichments in these elements as summarized in Table 1 The complete dataset is available by request from the first author. Considering the more expensive REE, monazite is enriched in $\mathrm{Nd}$ and Eu (respectively with 13.06 and 0.54 wt. \% REO) and xenotime is enriched in $\mathrm{Dy}, \mathrm{Yb}, \mathrm{Gd}$, and $\mathrm{Er}$ (respectively 4.77, 3.39, 3.15, 3.86 wt. \% REO) with a total of 18 wt. \% of HREO, in addition to the other main formula components such as $\mathrm{Ce}, \mathrm{P}, \mathrm{La}$ in monazite and $\mathrm{Y}, \mathrm{P}$ etc. in xenotime. Similar REE enrichment is known also from pegmatite provinces elsewhere, in their pegmatites and related secondary alluvial deposits. Zircon, thorite, uraninite showed no significant enrichment in REE. Other accessories may occur in still lower modal contents in the studied samples from the BPP.

The distribution of monazite and xenotime in the investigated samples is quite heterogeneous. The highest abundance of xenotime, with estimated modal contents of 0.005 to 0.01 wt. \% was observed in the aplite facies ("line rocks") of the Picuí granite (50 to 100 composite zircon+xenotime crystals, 50 to $200 \mu \mathrm{m}$ in size, were counted in several $22 \times 42 \mathrm{~mm}$ large, polished thin sections). This aplite occurs in decimeter- to meter thick sheets repeated in rhythmical alternation with layers of the other facies of the granite (Fig. 3). The xenotime in this aplite frequently occurs in a very conspicuous coaxial intergrowth with zircon, with compositionally co-variant oscillating crystal-growth zones, attesting the primary simultaneous magmatic crystallization of both (as shown in Fig. 5). Idiomorphic magnetite is another common accessory phase in the aplite and other facies of the Picuí granite.

The same rhythmical facies alternation is observed in the pegmatitic granite intrusions at Marcação (Fig 2), Galo Branco and Nova Palmeira-N (Fig. 4) (for details see Beurlen et al. 2009). In contrast to the Picuí granite, in this pegmatitic granite intrusion, monazite is the dominant REE-bearing accessory phase in the aplite facies instead of xenotime, and garnet (poor in REE) is the most common associated accessory mineral instead of magnetite. As example, in a representative thin section of the aplite facies from the Marcação pegmatitic granite, thirty grains of monazite and only four grains of xenotime, with enough size and polish quality for analyses were identified (sample HB 4201 in Table 1). Many monazite grains were found also in samples from the Nova Palmeira-N and Galo Branco pegmatitic granites and from the contact zones of the Carrascão and Quintos, Paraíba Tourmaline bearing pegmatites. 


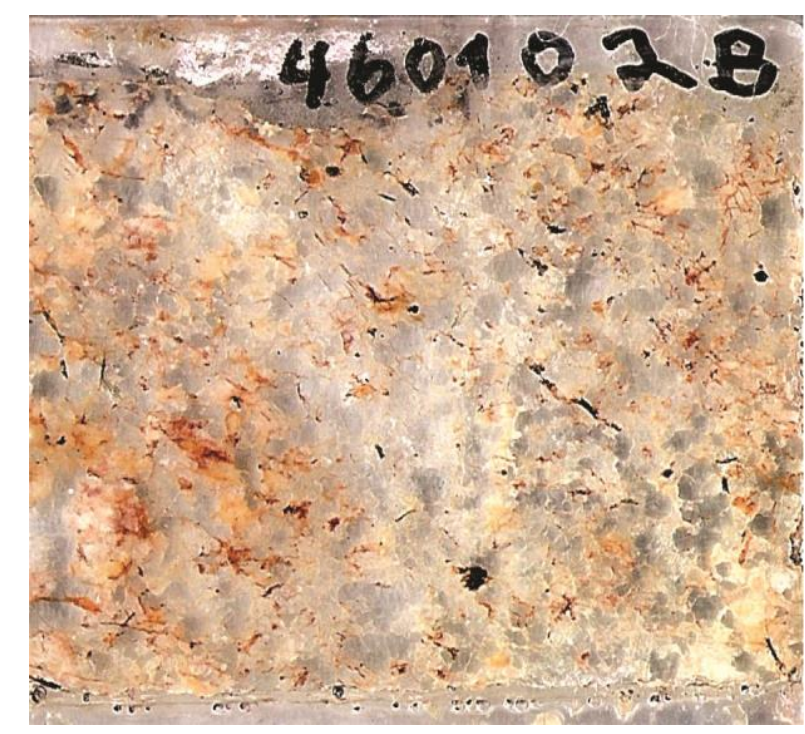

Figure 5 Polished thin section HB 460102B, of the banded sodic aplite from the Picuí pegmatitic-granite bench. Black dots are mostly xenotyme and zircon and some magnetite. The fine alternance of pink and beige bands simulating the garnet bearing "line rocks" in this case is given by variation of proportions of feldspar and quartz. The pink colored bands are the result of very fine impregnation of limonite at the borders and fractures of well-rounded quartz grains, macroscopically possible to be suspected to be garnet. Beige bands are richer in feldspars and low hydroxide impregnations.

Xenotime and monazite of these pegmatites and of the various coarsegrained facies of the pegmatitic granites show nearly identical REE distributions (and enrichments) than those of the aplite facies in the pegmatitic granites as shown in Fig. 6. Zircon in all facies of the various pegmatitic granite intrusions and in the pegmatites did not show significant REE enrichment. Hafnium values of the zircon grains of both, aplites and border zones of pegmatites, were observed to be nearly the same.

Five whole rock REE analyses of two facies of pegmatitic granite intrusions in the BPP (GR3 A and B) are available in da Silva, (1993) with a range between 50 and $80 \mathrm{ppm}$ total REE. Three, data are from a leucocratic fine to medium grained equigranular facies and the other two from an inequigranular facies with graphic quartz megaoikocrysts. The chondrite normalized data are included in Fig. 7, for comparison with the whole-rock data from the source-rocks in a REL - pegmatite field in Canada by Černý et al. (2005) and of the source-rock of the regolith-type deposit of Zudong (formerly known as ion-adsorption type) in China by $\mathrm{Li}$ et al. (2019). The estimated modal contents of xenotime and monazite and their ETR contents in the sodic aplite of the BPP, agree with whole-rock total REE contents around $100 \mathrm{ppm}$ and confirm the analyses by $\mathrm{Da}$ Silva (1993). These values are lower but in the same order of magnitude of the data of the source intrusion of the Zudong deposit, between 300 an 500 ppm (Li et al. 2019). For comparison in Fig. 7 the distribution of the chondrite normalized REE data in xenotime, monazite and zircon in the BPP is also included. The data for xenotime and monazite are two orders of magnitude higher than those of zircon.

REE data obtained by da Silva (1993) of some other granite intrusions (of the G 2 and G 3 groups according to Jardim de Sá, 1999), within the extent of the BPP but without a genetic relation 
with the pegmatites, may have even higher total REE contents (ranging between 100 and $300 \mathrm{ppm}$ ), but always with high chondrite nrmalized $\mathrm{La} / \mathrm{Lu}$ slope and low HREE values. These granite types were not examined in this study for the REE distribution in their accessory minerals, but could also be candidates for the formation of secondary ion-adsorption deposits if preserved at favorable paleogeographic conditions as already proven for the pegmatitic-granites ( $\mathrm{G} 4$, according to Jardim de Sá, 1994, or GR 3A and B, in Da Silva 1993) and the deeply kaolinized pegmatites.
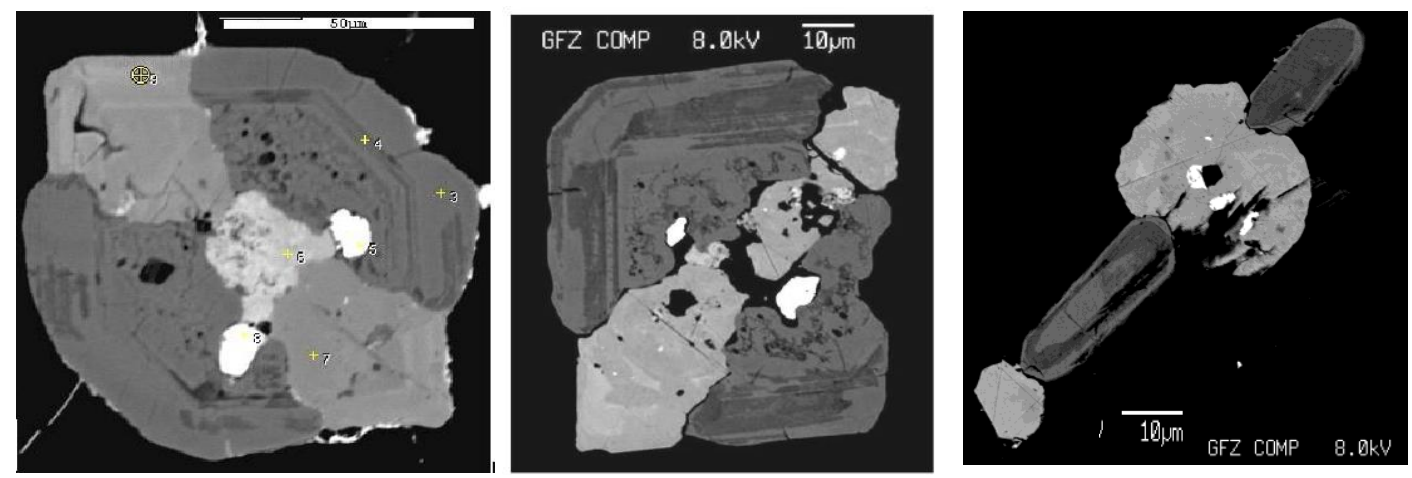

Figure 6. BSEI (Backscattered electron images) of composite zoned grains of zircon (darker gray) and xenotime (lighter gray), with small idiomorphic uraninite inclusions (almost white). Zircon and xenotime crystals in the two images at the left show oscillating clearly covariant compositional variations indicating a co-genetic primary-magmatic growth. In the core of the grain in the left a small grain of metamict thorite can be observed. White scale bar is 50 micrometers long. Ages obtained from both, the uraninite and xenotime are the same. Uranium contents in zircon are too high to allow dating on this mineral with the classical methods. 
Hartmut Beurlen et al.

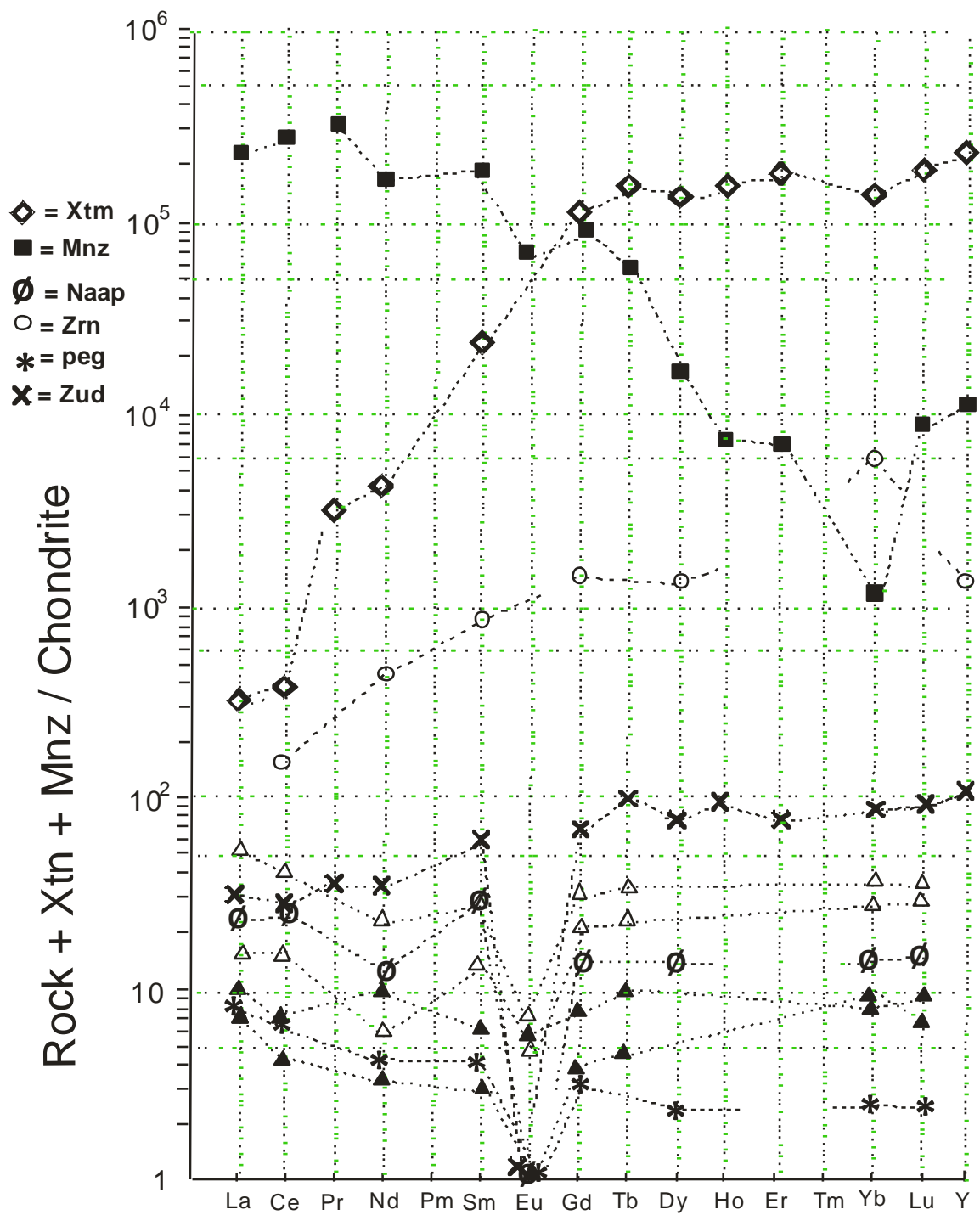

Figure.7 Chondrite-normalized REE distribution in xenotime (diamonds, Xtm) monazite (full squares, Mzt) and zircon (circles, Zrn) in comparison with whole rock G3a (medium grained leucogranite facies-empty triangles) and b (pegmatitic facies full triangles) by da Silva (1993) and sodic banded aplite facies (dashed circle,Naap) and pegmatitic facies (stars, peg) by Cerny et al. (2005b), and (xcrosses, zun) Zundong granite, Jiangxi-China (by Li et al 2019). 
Table 1: Summary of representative REE analyses from the BPP, NE-Brazil.

\begin{tabular}{|c|c|c|c|c|c|c|c|c|}
\hline & \multirow{2}{*}{$\begin{array}{l}\text { Mindata } \\
\text { Type Xtm }\end{array}$} & \multirow{2}{*}{$\begin{array}{l}\text { HB460102 Xtm } \\
\text { Mean }(n=38)\end{array}$} & \multicolumn{2}{|c|}{ HB460101 Xtm } & \multicolumn{2}{|c|}{ HB4201 Xtn HB4201 Mnz } & \multicolumn{2}{|c|}{ HB460102 Zrn } \\
\hline & & & Mean $(n=52)$ & Std. Dev. & Mean $(n=4)$ & Mean $(n=30)$ & Mean $(n=16)$ & Std. Dev \\
\hline $\mathrm{La}_{2} \mathrm{O}_{3}$ & - & 0.013 & 0.014 & 0.021 & 0.004 & 9.184 & - & - \\
\hline $\mathrm{Ce}_{2} \mathrm{O}_{3}$ & - & 0.040 & 0.052 & 0.029 & 0.062 & 25.758 & 0.016 & 0.019 \\
\hline $\mathrm{Pr}_{2} \mathrm{O}_{3}$ & - & 0.037 & 0.028 & 0.032 & 0.049 & 3.323 & - & - \\
\hline $\mathrm{Nd}_{2} \mathrm{O}_{3}$ & - & 0.327 & 0.382 & 0.047 & 0.305 & 13.056 & 0.031 & 0.038 \\
\hline $\mathrm{Sm}_{2} \mathrm{O}_{3}$ & 0.49 & 0.629 & 0.644 & 0.054 & 0.596 & 4.284 & 0.022 & 0.036 \\
\hline $\mathrm{Eu}_{2} \mathrm{O}_{3}$ & 0.07 & bdl & bdl & $b d l$ & bdl & 0.537 & - & - \\
\hline $\mathrm{Gd}_{2} \mathrm{O}_{3}$ & 2.69 & 3.252 & 3.169 & 0.189 & 3.182 & 2.797 & 0.045 & 0.038 \\
\hline $\mathrm{Tb}_{2} \mathrm{O}_{3}$ & 0.58 & 0.677 & 0.647 & 0.069 & 0.815 & 0.243 & - & - \\
\hline $\mathrm{Dy}_{2} \mathrm{O}_{3}$ & 4.93 & 4.935 & 4.714 & 0.366 & 5.783 & 0.658 & 0.053 & 0.073 \\
\hline $\mathrm{Ho}_{2} \mathrm{O}_{3}$ & 1.27 & 1.005 & 0.963 & 0.083 & 0.863 & 0.044 & - & - \\
\hline $\mathrm{Er}_{2} \mathrm{O}_{3}$ & 4.05 & 3.978 & 3.908 & 0.218 & 2.920 & 0.144 & - & - \\
\hline $\mathrm{Yb}_{2} \mathrm{O}_{3}$ & 4.36 & 3.473 & 4.058 & 0.236 & 3.190 & 0.027 & 0.125 & 0.091 \\
\hline $\mathrm{Lu}_{2} \mathrm{O}_{3}$ & 0.87 & 0.790 & 0.904 & 0.057 & 0.764 & 0.037 & - & - \\
\hline $\mathrm{Y}_{2} \mathrm{O}_{3}$ & 46.49 & 44.204 & 44.282 & 1.156 & 45.498 & 2.137 & 0.227 & 0.320 \\
\hline $\mathrm{P}_{2} \mathbf{O}_{5}$ & 34.37 & 31.120 & 31.858 & 0.907 & 32.635 & 27.592 & 0.230 & 0.186 \\
\hline $\mathrm{SiO}_{2}$ & 0.31 & 1.297 & 1.314 & 0.520 & 1.468 & 1.809 & 32.523 & 0.809 \\
\hline $\mathrm{ThO}_{2}$ & - & 0.857 & 1.049 & 0.706 & 1.057 & 6.540 & 0.036 & 0.040 \\
\hline $\mathrm{UO}_{2}$ & - & 0.954 & 1.277 & 0.508 & 1.473 & 0.342 & 0.308 & 0.187 \\
\hline $\mathrm{PbO}$ & - & 0.090 & 0.113 & 0.051 & 0.137 & 0.186 & 0.009 & 0.013 \\
\hline $\mathrm{CaO}$ & - & 0.050 & 0.040 & 0.047 & 0.040 & 0.816 & 0.084 & 0.140 \\
\hline $\mathrm{Al}_{2} \mathrm{O}_{3}$ & - & 0.000 & 0.000 & 0.000 & 0.000 & 0.190 & 0.138 & 0.127 \\
\hline $\mathrm{FeO}$ & - & 0.202 & 0.140 & 0.271 & 0.401 & 0.089 & 0.274 & 0.214 \\
\hline $\mathrm{ZrO}_{2}$ & - & - & - & - & - & - & 63.716 & 1.156 \\
\hline $\mathrm{HfO}_{2}$ & - & - & - & - & - & - & 2.481 & 0.251 \\
\hline $\mathrm{TiO}_{2}$ & - & - & - & - & - & - & 0.007 & 0.009 \\
\hline $\mathrm{Sc}_{2} \mathrm{O}_{3}$ & - & - & - & - & - & - & 0.022 & 0.012 \\
\hline $\mathrm{Tm}_{2} \mathrm{O}_{3}$ & 0.70 & - & - & - & - & - & - & - \\
\hline Total & 101.18 & 97.932 & 99.556 & 0.974 & 101.240 & 99.795 & 100.347 & 1.302 \\
\hline
\end{tabular}

- Abbreviations: $\mathrm{Xtm}=$ xenotime, $\mathrm{Mnz}=$ monazite, $\mathrm{Zrn}=\mathrm{zircon}$. Columns: Mindata refers to a single analysis of a typical pegmatite Xnt from Norway; HB460102 refers to analyses of a sample of the aplite facies in the Picuí pegmatitic granite; HB460101 another sample of the same aplite facies. HB4201 refers respectively to Xtm and Mnz results of a polished thin section of the aplite facies from the Marcação granitic-pegmatite; last column HB460102 are Zrn data of the same section in column 2. Hyphens = not analysed.

\section{DISCUSSION AND CONCLUSIONS}

The analytical results confirmed that xenotime and monazite in aplites and pegmatites of the BPP are the only mineral groups with significant enrichment in highly prized REE (Fig. 7 ), in proportions similar to that observed in other pegmatite provinces or alkaline granites. Both minerals however occur in low mean modal concentrations in these rocks (around $0.01 \%$ or less) even in both, the enriched aplitic facies of the parental granites and the border zones of the complex pegmatites. The REE concentrations are far below the mining grade for hard-rock exploitation. There is however a good chance of secondary REE deposits as: a) alluvial placer deposits rich in xenotime as those reported by Sengupta \& van Gosen (2015) from some Southeast-Asian countries; and b) ion-adsorption (or regolith) type deposits as reported by Voncken (2016) and Li et al. (2019) from China. Both deposit types could be 
expected within or close to the extent of the BPP. Type b) occurrences could be related to clay- and iron-hydroxide-rich alteration along the unconformity between the Proterozoic BPP granites and the plateau formed by an early Cenozoic siliciclastic couverture (Serra dos Martins Formation), later uplifted and eroded during the younger Cenozoic, and today preserved only as "mesetas" (Morais Neto \& Alkmin 2001). Coastal heavy mineral Ti-deposits exploited 250 $\mathrm{km}$ eastward of the BPP, occur close to the mouth of rivers draining the BPP and older basement. Probably due to the large distance from the BPP, they contain only insignificant contents of monazite and no xenotime.

\section{Acknowledgements}

Special gratitude is dedicated to the GFZ-Potsdam (Center for Geoscientific Research - HelmholtzFoundation, Potsdam, Germany) for the permission of the free acquisition of a great part of the analytical work (EMPA, Raman, FI-lab) along the last two decades by Prof. Dr. Wilhelm Heinrich. Particularly for the efficient assistance at the EMPA facility at the GFZ we strongly acknowledge Onna Appelt.. We gratefully express our gratitude to several co-authors of previous papers listed in the references. This work was supported by grants APQ 471064/20068, PQ 302-348/2007-7, 302076/2010-7 and $307204 / 2013-8$ of the Brazilian Council for Scientific Research (CNPq).

\section{REFERENCES}

Armstrong, J.T. 1995. CITZAF: a package of correction programs for the quantitative electron microbeam X-ray-analysis of thick polished materials, thin films, and particles. Microbeam Anal. 4: 177 $-200$
Baumgartner, R., Romer, R.L., Moritz, R., Sallet, R., Chiaradia, M., 2006. Columbite-tantalite-bearing granitic pegmatites from the Seridó Belt, NE Brazil: genetic constraints from $\mathrm{U}-\mathrm{Pb}$ dating and $\mathrm{Pb}$ isotopes. The Canadian Mineralogist, 44, 69-86.

Beurlen, H., Da Silva, M.R.R., Thomas, R., Soares, D.R., Olivier, P., 2008. $\mathrm{Nb}$-Ta-(Ti-Sn)-oxide mineral chemistry as tracers of rareelement granitic pegmatite fractionation in the Borborema Province, northeast Brazil. Mineralium Deposita, 43, 207228.

Beurlen, H., Rhede, D., Da Silva, M.R.R., Thomas, R., Guimarães I.P., 2009. Petrography, geochemistry and chemical electron microprobe U-Pb-Th dating of pegmatitic granites in the Borborema Pegmatite Province, NE-Brazil: a possible source of the rare-element granitic pegmatites. Terrae 6, 59-71.

Beurlen, H., Thomas, R , Da Silva, M.R.R., Müller, A.B.,Rhede, D., Soares, D.R. 2014. Perspectives for $\mathrm{Li}^{-}$and $\mathrm{Ta}$-mineralization in the Borborema Pegmatite Province, NE-Brazil: A review. Journal of South American Earth Sciences, 56: 110-127.

Brasil, 1998. Mapa Geológico do Estado do Rio Grande do Norte. Brasil. Departamento Nacional da Produção Mineral (DNPM)Companhia de Pesquisa de Recursos Minerais (CPRM, Brazilian Geological Survey) /Federal University of Rio Grande do Norte (UFRN).(Geologic map of the State of Rio Grande do Norte, with legend in portuguese). Brasil, 2002. Mapa geológico do Estado da Paraíba. Departamento Nacional da Produção Mineral (DNPM) -Companhia de Pesquisa 
de Recursos Minerais (CPRM, Brazilian Geological Survey) / Companhia do Desenvolvimento de Recursos Minerais (CDRM, State of Paraíba Geological Survey), Recife, Brasil, (Geologic map of the State of Paraíba with legend in portuguese).

Brito Neves B.B., Fuck, R.A., 2013. Neoproterozoic evolution of the basement of the South-American platform. Journal of South American Earth Sciences, 47, 7289.

Campos, M.F. Castro, J.A. Rodrigues D..(2015) Terras-Raras: Aplicações e Tendências do Mercado para os Próximos Anos. $3^{\circ}$ Seminário Brasileiro de Terras Raras, Univ. Federal Fluminense (UFF), Volta redonda Rio de Janeiro, 30 pages.

Černý, P., Ercit, T.S., 2005. The classification of granitic pegmatites revisited. The Canadian Mineralogist, 43, 20052026.

Černý, P., Masau, M., Goad , B.E., Ferreira, K., 2005. The Greer Lake leucogranite Manitoba and the origin of lepidolite-subtype granitic pegmatites. Lithos, 80, 305-321.

da Silva, M.R.R., 1993. Petrographical and geochemical investigations of pegmatites in the Borborema Pegmatitic province of Northeastern Brasil. Ph.D. thesis, Ludwig Maximilian Universersität München. Germany.

da Silva, M.R.R., Höll, R., Beurlen, H., 1995. Borborema Pegmatitic Province: geological and geochemical characteristics. Journal of South American Earth Sciences, 8, 355-364.

Dirac, F.M., Ebert, H., 1967. Isotopic ages from the pegmatite provinces of eastern Brazil. Nature, 215, 948-949.
Ebert, H., 1970. The Precambrian geology of the "Borborema" belt (States of Paraíba and Rio Grande do Norte) and the origin of its mineral provinces. Geologische Rundschau (International Journal of Earth Sciences), 59(3), 12941327.

Haxel, G.B., Hedrick, J.B., and Greta J. Orris, G.J. 2002 "Rare Earth Elements-Critical Resources for High Technology. 5 pages. USGS Online.http://geopubs.wr.usgs.gov /fact-sheet/fs087-02/

Jardim de Sá, E.F., 1994. A Faixa Seridó (Província Borborema, NE do Brasil) e seu significado geodinâmico na cadeia Brasiliana/Panafricana. Ph.D Thesis, University of Brasília, Brazil, 762pp. (The Seridó Belt, Borborema Province, NE-Brazil, in Portuguese).

Jardim de Sá, E.F., Legrand, J.M., McReath, I, 1981. Estratigrafia de rochas granitóides na Região do Seridó (RN-PB) com base em critérios estruturais. Revista Brasileira de Geociências, 11, 5057.("Stratigraphy of granitoid rocks in the Seridó region (RN-PB) based on structural criteria", in portuguese).

Li, MY.H, , Zhou, M., William Jones, A.E 2019 The Genesis of Regolithhosted Heavy rare earth element deposits: insights from the worldclass Zudong Deposit in Jiangxi Province, South China. Econ. Geol. 114(3): 541-568.

Montel, J.M., Veschambre,M., \& Nicollet. C. (1994). Datation de La monazite à La microsonde életronique. C.R. Acad. Sci. Paris, 318, série II, 1489-1495.

Morais Neto, J.M. \& Alkmin, F.F.2001 A deformação das coberturas terciárias do planalto da Borborema (BB-RN) e seu 
significado tectônico. Revista Bras Geologia. 31 (1): 95-106.

Nakamura, N., 1974. Determination of REE, $\mathrm{Ba}, \mathrm{Fe}, \mathrm{Mg}, \mathrm{Na}$ and $\mathrm{K}$ in carbonaceous and ordinary chondrites. Geochimica et Cosmochimica Acta, 38, 757-775.

Rhede, D., Wendt, I. \& Förster, H.J. (1996) A three dimensional method for calculation ind4ependent chemical $\mathrm{U} / \mathrm{Pb}$ - and $\mathrm{Th} / \mathrm{Pb}$-ages of accessory minerals. Chemical Geology 130, 247-253.

Sengupta D., \& van Gosen. B. 2015 Placer-type Rare Earth Element Deposits. In Reviews in Econ. Geol. 18. pp 81-100.

Sreevidya P, Jagadeesh, A, Riju, B. 2017. Air Conditioning using Magnetic Cooling Effect. 2017 IEEE International Conference on Technological Advancements in Power and Energy ( TAP Energy ), Ext. Abstr., 5 pages.

Statistica (2019) Forecast of rare earth oxide prices worldwide from 2014 to 2025* https://www.statista.com/statistics /449838/forecast-average-rareearth-oxide-prices-globally/

Suzuki, K. \& Adachi, M. (1991). Precambrian provenance and Silurian metamorfism of the Tsubonosawa paragneiss in the South Kitakami terrane,Northeast Japan, revealed by the chemical Th-U-total $\mathrm{Pb}$ isochron ages of monazite, zircon and xenotime. Geochem. J. 25, 357-376 van Schmus, W.R., Brito Neves, B.B., Williams, I.S., Hackspacher, P. C., Fetter, A.H., Dantas, E.L., Babinski, M., 2003. The Seridó Group of NE Brazil, a late Neoproterozoic pre- to syncollisional basin in West Gondwana: insights from SHRIMP U-Pb detrital zircon ages and Sm-Nd crustal residence (TDM) ages. Precambrian Research, 127, 287-327.

Voncken, J.H.L. (2016) The Rare Earth Elements: An Introduction. 127 pp. Chapter 2: The Ore Minerals and Major Ore Deposits of the Rare Earths, 15-51

Webber, K.L., Falster, A.U., Simmons, Wm.B., Foord, E.E., 1997. The role of diffusion controlled oscillatory nucleation in the formation of line rock in pegmatite-aplite dikes. J. Petrol. 39, 1777-1791. 